\title{
DE BEATOS E INCAS. PROCESIONES INDÍGENAS EN LA RELACIÓN DE 1610
}

\author{
ON BEATI AND INCAS. INDIGENOUS PROCESSIONS \\ IN THE 1610 RELACIÓN
}

Paula Martínez Sagredoa

Los albores del siglo xvir encontraron en el Cuzco una ciudad que había dejado de ser la cabecera del virreinato en pos de la ciudad de Lima, y que ya había vivido guerras civiles, campañas de extirpación de idolatrías y la desaparición de los últimos descendientes Incas. Presentamos en este artículo el texto completo de la Relación de 1610 donde se relatan las ceremonias para festejar la beatificación de Ignacio de Loyola, antecedida del contexto histórico y acompañada de notas críticas que permiten entender el momento festivo en el que las comunidades indígenas participan de esta fiesta con sus "bailes y música", permitiéndonos reconstruir hoy algunos mecanismos de mantención de la memoria incaica al interior de estas comunidades.

Palabras clave: Fiestas, Danzas, Cuzco colonial, Jesuitas, Lingüística misionera, Incas, Memorias.

At the turn of the 17th century, the headquarters of the Viceroyalty had moved to Lima from the city of Cuzco, which had suffered civil wars, campaigns against idol worship, and the disappearance of the last descendants of the Incas. In this article we present the complete text of the Relacion, preceded by a description of the historical context and accompanied by critical notes to enable the reader to understand the festivities surrounding indigenous communities' participation in the beatification of Ignacio de Loyola, including their "dances and music," to allow today's audience to understand some of the mechanisms by which the Inca memory was kept alive within those communities.

Keywords: Festivals, Dances, Colonial Cuzco, Jesuits, Missionary linguistics, Incas, Memory.

\section{LA BEATIFICACIÓN DE IGNACIO DE LOYOLA}

A comienzos de mayo del año 1610 se recibió en Cuzco la noticia de la beatificación de Ignacio de Loyola. Fallecido el 31 de julio de 1556, Ignacio de Loyola fue autor de los Ejercicios espirituales y fundador de la orden de la Compañía de Jesús, cuyos miembros son conocidos como jesuitas. Beatificado en 1609 por Pío XI, la noticia llegaría al Cuzco varios meses después de su muerte, cuando la orden se encontraba en un vigoroso desarrollo en el virreinato peruano, a donde arribó el año 1568. ${ }^{1}$ En 1555, el virrey Andrés Hurtado de Mendoza había solicitado al comisario en España, Francisco de Borja, la llegada de religiosos de la orden, solicitud que solo se vio concretada hacia 1566 cuando Francisco de Borja, recién elegido General de la Compañía, aceptó la petición de Felipe in de enviar jesuitas a la Florida y al Perú. Relata Diego de Esquivel y Navia que no fue sino hasta principios de enero de 1571 que entraron los jesuitas a la ciudad del Cuzco, donde intentaron fundar un colegio en el antiguo palacio de Huayna Cápaq o Amarucancha.

\footnotetext{
A Paula Martínez Sagredo, Universidad de Tarapacá, Departamento de Ciencias Históricas y Geográficas, Arica, Chile; Proyecto ANID/ CONICYT-FONDECYT 11190356. ORCID: 0000-0002-7881-3859. E-mail: pmartinezsagredo@gmail.com
} 
La llegada de la orden al virreinato peruano implicó la división del territorio en cuatro zonas: (1) Nueva Granada y Quito; (2) Charcas; (3) Chile y (4) Perú; y su dispersión implicó la ocupación del espacio con un fin evangelizador y educativo lo que, en la práctica, se expresó en el desarrollo de doctrinas de profundo impacto social, como las de Juli y Huamanga, y en el establecimiento de escuelas para hijos de caciques, como la del Cuzco (1621). Entre 1570 y 1605 se fundaron parroquias de indios o doctrinas en la Audiencia de Lima, Huarochirí, Cercado, Cuzco, Arequipa. En la Audiencia de Charcas se conformaron los colegios de la Paz y Chuquisaca, la doctrina de Juli (Perú) y, finalmente, en las residencias de Potosí y Santa Cruz de la Sierra.

Los jesuitas, a diferencia de las restantes órdenes religiosas, tuvieron un rol particularmente considerable en el Cuzco, por una parte, debido a la relación que fueron estableciendo con la nobleza incaica, y por otra, a la intercesión política que realizaron frente al virrey Toledo por la ejecución de Túpaq Amaru (fig. 1). Según lo que se indica en la Relación que aquí presentamos, el fiato entre la Compañía y los Incas llegó a tal punto que, semanas después de la fiesta de 1610, "los descendientes de los Incas y señores de esta tierra hicieron juramento y voto [...] de tener por su patrón al dicho santo [Ignacio de Loyola]".

Los lazos de los jesuitas con la población indígena cuzqueña son profundos y se adentran en la genealogía de los Incas coloniales. Hay que recordar que Martín García Oñez de Loyola, soldado español y sobrinonieto del fundador de la Compañía de Jesús, San Ignacio de Loyola, se casó con Beatriz Clara, hija del Inca Sayri Túpaq, hermano mayor de Túpaq Amaru. La hija del matrimonio - doña Ana María Lorenza de Loyola- se casó en España con el nieto de san Francisco de Borja, anterior tercer general de la orden jesuita (Klaiber 2007: 18). Estas alianzas que trascendían lo religioso permitieron a los jesuitas ostentar un rol también político y social que es notable en la Relación que aquí presentamos (fig. 2).

Por otra parte, la orden jesuita fue reconocida en el virreinato del Perú por su alta capacidad de adaptación y negociación cultural, ejemplo de lo cual fueron los éxitos logrados en reducciones como Juli y Huamanga. Recordemos que después del Concilio de Trento y del III Concilio Limense, la orden Jesuita se encargaría de la llegada de la primera imprenta a América del Sur, la que se instaló en la ciudad de Lima a cargo de Antonio Ricardo, lugar donde se imprime tanto la Relación cuz-

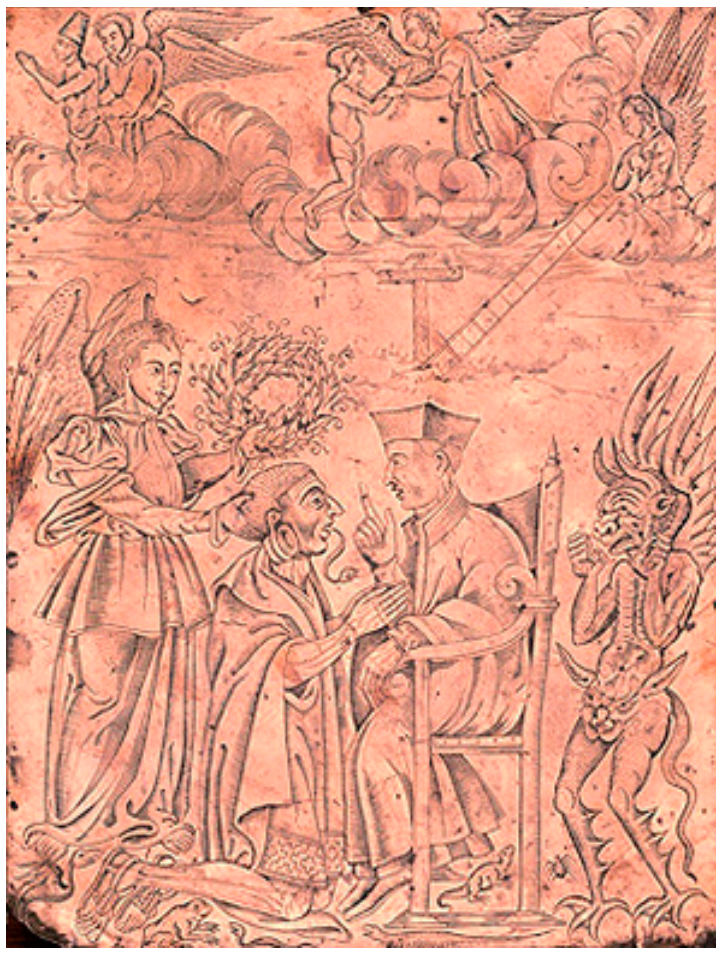

Figura 1. Catequización de Tupac Amaru I a cargo del jesuita Alonso de Barzana (grabado sobre lámina de cobre, 1615. Colección Barbosa-Stern). Figure 1. Tupac Amaru catechization by Jesuit Alonso de Barzana (copper sheet engraving, 1615, Barbosa-Stern collection).

queña como su símil limense que comentaremos más adelante. En los albores del siglo xvir, la Compañía se encontraba en una renovación producto de la contrarreforma (Estenssoro 2005). Cabe preguntarse, entonces si las fiestas celebradas en honor a San Ignacio de Loyola, tanto en Cuzco como en Lima, así como su posterior difusión en formato impreso, tuvo alguna relación con este proceso histórico. ${ }^{2}$

\section{El Cuzco de comienzos del siglo XVII}

Hacia 1610 la población indígena cuzqueña había sido reducida en cinco parroquias (proceso de reordenación que encabezó Polo de Ondegardo en 1559) a las que luego se añadieron tres más durante el gobierno de Francisco de Toledo. La primera parroquia fue la de Santa Ana, erigida en el antiguo barrio de Carmenca, donde prehispánicamente habitaban los cañaris y los chachapoyas. La segunda fue la de San Cristóbal, en Colcampata, bajo Saqsaywamán, barrio en el que estaba el palacio de Manco Cápaq y luego de Paullu Inca. La 


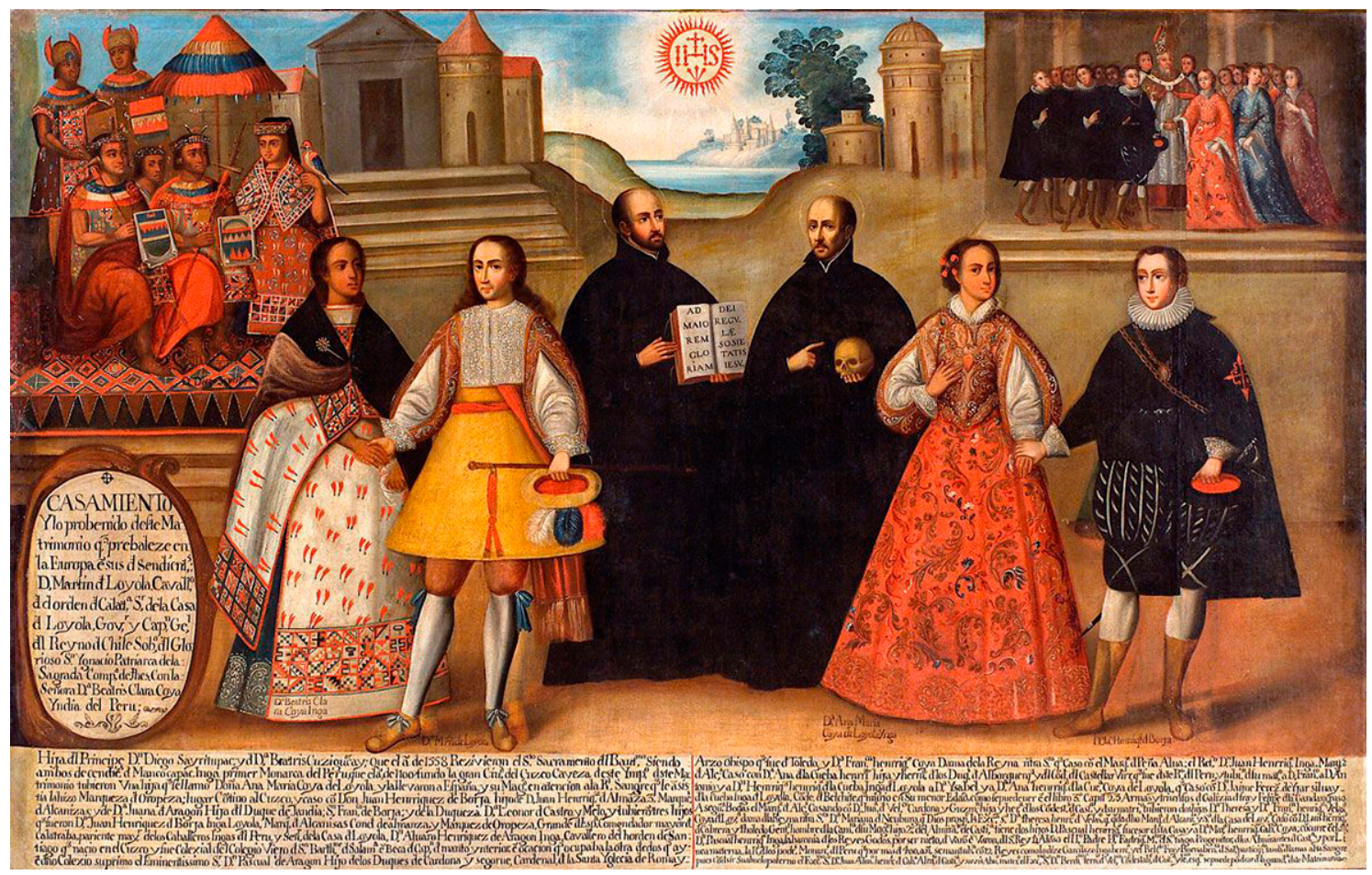

Figura 2. Matrimonios de Martín Oñez de Loyola con Beatriz Clara Coya y de Juan de Borja con Lorenza Nusta (Anónimo escuela cuzqueña, ca. 1725, Museo Arzobispal del Cuzco). Figure 2. Martín Oñez de Loyola and Beatriz Clara Coya's and Juan de Borja and Lorenza Ñusta's weddings (Anonymous from Cuzco school, circa 1725, Archbishop's Museum of Cuzco).

tercera parroquia correspondía a San Blas, en el barrio de Tococachi, lugar donde se encontraron en las primeras campañas de extirpación de idolatrías las momias de los Incas Viracocha, Topa Inca Yupanqui, Huaina Cápaq y de las coyas Mama Runtu y Mama Ocllo. La cuarta parroquia, San Sebastián, se encontraba a cinco km del Cuzco, por el camino al Collasuyu. La parroquia de los Reyes o de Belén estaba en el barrio de Cayaocachi, donde se albergaban los mitmaqunas. Las tres parroquias que se añadieron posteriormente fueron San Pedro (1565), que correspondía al anterior barrio de Hospital de Naturales, la de Santiago, en el barrio de Chaquilchaca, junto a Belén y San Jerónimo, sin embargo, la población del obispado del Cuzco congregaba una zona bastante más amplia que la de esas parroquias y que posiblemente es la que llegaba hasta la ciudad con motivo de las grandes celebraciones o actos públicos.

\section{La Relación y su contenido}

La Relación consta de siete folios, escritos en español, a los cuales se añaden en 1622 tres folios más escritos en latín con motivo de la canonización de san Ignacio. ${ }^{4}$ Impresa en 1610 en la imprenta de Francisco del Canto en Lima (el segundo de los impresores traídos al virreinato a cargo de los jesuitas), no se identifica autor para el documento. ${ }^{5}$ Algunos rasgos parecen delatar un cierto descuido en la revisión del texto, especialmente en la errónea escritura de vocablos como "ofreciempo" (por ofreciendo), "lagradas" (por sagradas), "agnns" (por agnus), etc. Se encuentra custodiado en la Biblioteca Nacional del Perú, Lima, bajo la signatura A-A3.

Sobre la festividad que se relata en esta Relación hay poca información anexa. Muy escuetamente relata Esquivel y Navia en sus Noticias cronológicas de la gran ciudad del Cuzco que "Por el mes de mayo de 1610 se celebraron varias fiestas en esta ciudad por la beatificación de San Ignacio de Loyola, fundador de la sagrada Compañía de Jesús [...] y a 26 de junio de dicho año los descendientes de los Incas y señores de esta tierra hicieron juramento y voto ante el Cabildo, Justicia y Regimiento de tener por su patrón al dicho santo según consta a la primera foja del dicho libro [16 del cabildo secular]" (Esquivel y Navia 1980, Tomo II: 11). La noticia 

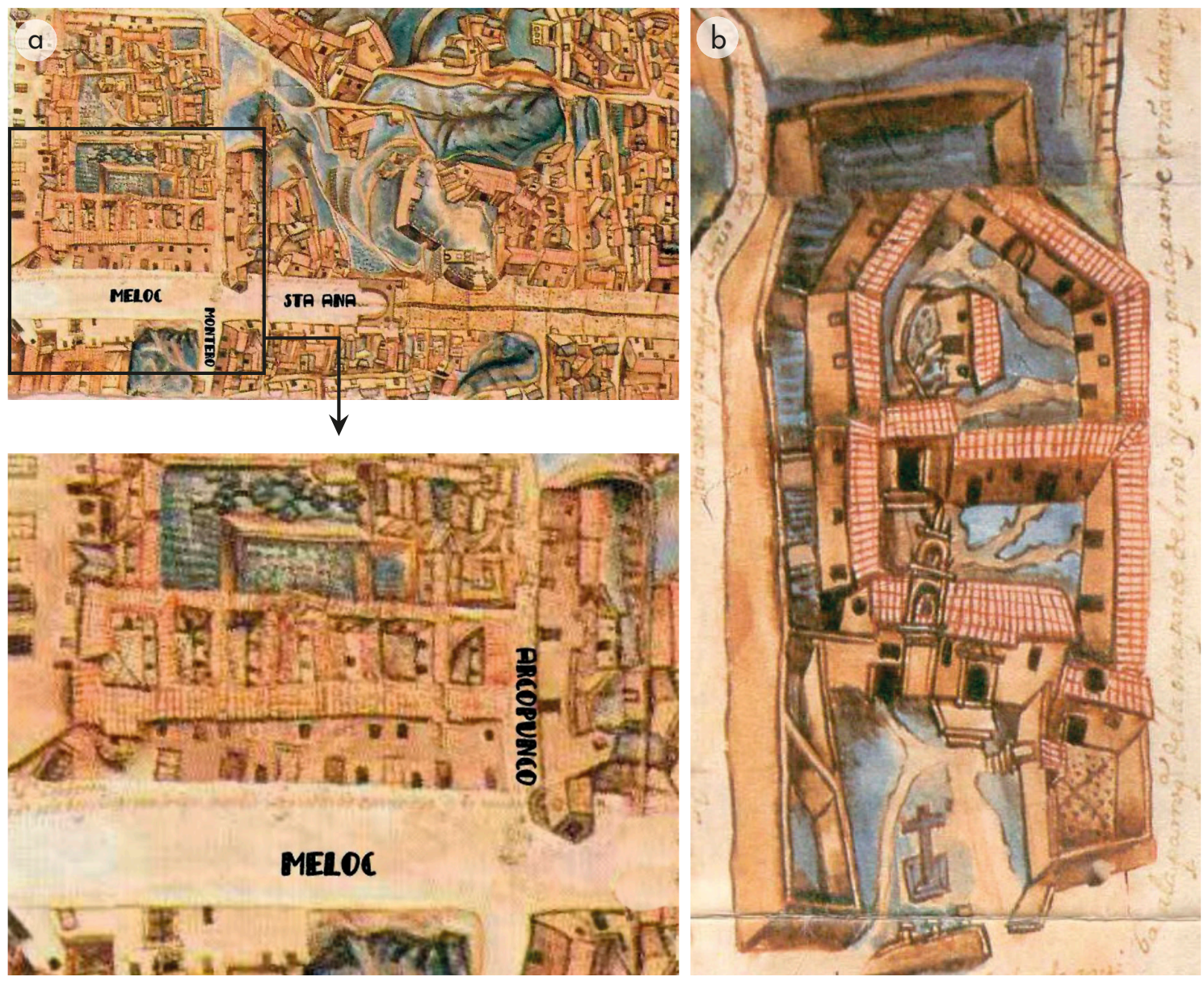

Figura 3: a) Plano de la ciudad del Cusco $1643 ;{ }^{3}$ b) detalle del plano: Parroquia del Hospital de Naturales, lugar al que fueron reducidos los descendientes del Inca Lloque Yupanqui (Esquivel Coronado 2015: 9). Figure 3: a) Cuzco city plan, 1643; b) plan detail: Hospital de Naturales Parish, where the Inca Lloque Yupanqui's descendants were reduced (Esquivel Coronado 2015: 9).

oficial de la beatificación ocurrió en Lima el 16 de abril del mismo año y serían el virrey Juan de Mendoza y Luna y el arzobispo de Lima, Bartolomé Lobo Guerrero, quienes ordenaron los homenajes en todo el territorio virreinal. Existen dos relatos sobre estas fiestas. Uno para la ciudad del Cuzco y otro para la ciudad de Lima, ambos fechados el mismo año. La diferencia entre uno y otro radica precisamente en el protagonismo indígena del primero y de españoles y criollos en el segundo.

Una versión resumida de esta Relación anónima fue hecha por Horacio Villanueva en 2009 y en el mismo año por Carlos Romero, donde solo replican las procesiones indígenas (folio 4 en adelante) y ha sido citada con cierta frecuencia para ilustrar la presencia de las élites indígenas en los nuevos escenarios coloniales. ${ }^{6}$ Estenssoro, en este sentido, señala que todas estas manifestaciones, que duraron 25 días, estaban encaminadas a recordar el antiguo poderío de los incas y, a través de ello, reforzar simbólicamente la alianza de la orden ignaciana con la élite indígena es decir, en fin de cuentas, el poder de la Compañía. El baile formaba parte de las festividades (Estenssoro 1992: 397).

De la Puente (2018), por otra parte, remarca que es posible leer algunos aspectos de la participación de la nobleza incaica en esta fiesta en términos políticos de una extrema relevancia y actualización. Para representar su República, cada noble representaba a uno de los antiguos emperadores y panacas de las cuales ellos mismos descendían. Para De la Puente, el hecho de que Don Alonso (hijo ilegítimo de Paullu Inca, y nieto de Guayna Cápac) encabezara la procesión es indicio de la relevancia e inmeditez de los eventos ocurridos en 
España, donde Melchor Inca, tío de don Alonso, era en ese momento parte de la corte real. Recordemos que Don Melchor era bisnieto de Huayna Cápaq, último gobernante Inca indiscutido. Es importante recordar aquí que fue en 1545, en la Real Cédula del 9 de mayo, que Carlos v autoriza a los nobles indígenas para escoger un alférez real de entre los descendientes de Huayna Cápaq bajo la condición de estar inscritos en alguna de las parroquias del Cuzco. Al respecto, Ruiz de Pardo (2004: 19) señala que esta institución de Alferazgo Real de indios nobles fue un rasgo distintivo de la ciudad del Cuzco frente a otras ciudades de los distintos virreinatos, pues no existió ni en el de Nueva España ni en el de Nueva Granada. Empero, no quisiéramos adelantarnos en el análisis de las festividades sin primero conocer el texto en cuestión. Volveremos, por lo tanto, sobre este punto más adelante.

\section{EL TEXTO DE LA RELACIÓN}

[Fol. 1]

Relación de las fiestas que en la civdad de Cuzco se hizieron por la beatificación del bienaventvrado Ignacio de Loyola, fundador de [la] Compañía de Iesús, a pedimento de don Fernando de Vera y Padilla

A los dos de mayo de 1610 llegó al Cuzco la alegre nueua de la Beatificación del bienaventurado padre Ignacio, y fue recibida con general aplauso y demostración de alegría, no solo de los padres de la Compañía, sino de todas las sagradas religiones, españoles e indios, que por ser tan extraordinaria y ser común voz que no se han hecho en esta ciudad desde su fundación fiestas que ygualen a estas, ha parecido referirlas aquí con la breuedad posible.

Luego que se tuuo esta nueva el día dicho (que fue el tercer domingo después de Pascua a las tres de la tarde) y con ella el treslado [sic] autoriçado de la beatificación, se dio parte del por medio de los padres de la Compañía a los dos cabildos ecclesiástico y seglar, los quales acudieron luego a la Compañía a dar el parabién desta nueua, con esta demonstración se diuulgó por toda la ciudad dentro de dos horas y vinieron a hacer lo mismo todas las lagradas [sic] religiones y demás caualleros, dando todos muestras de contento y ofrecienpo [sic] de su parte celebrar aquella fiesta como propia. La primera demonstración que se hizo fue que aquella noche vuo repique general de campanas en todas las iglesias de la cathedral, monasterios y parochias, añadiéndose al que vuo en la Compañía de Jesús música de chirimías y otros instrumentos. A prima noche se cantó en la Compañía vn Te Deum laudamus ${ }^{8}$ solene [sic] con la música de la catedral que es escogida a que concurrió tanta gente que no cabía en la iglesia. Estaua en la capilla mayor vn altar grande muy bien adornado, en que se puso vna imagen de bulto del bienaventurado Padre Ignacio y a sus lados otras dos del B. Francisco Xauier y B. Stanislao de la misma Compañía. Causó grande admiración ver que en tiempo de dos horas se vuiesse puesto y adornado la iglesia y altar tan bien que parecía se auia sabido esta nueua dos días antes. Acudieron al Te Deum laudamus todas las sagradas religiones en forma de conuento y señalóse la del bienauenturado Padre Sancto Domingo, q[ue] vino de su casa en procesión y con chirimías cantando el Te Deum laudamus y acabólo entrando en la Compañía delante del altar del Beato Ignacio, diciendo su anthiphona y oración. Fue necesario por la mucha gente que concurrió tener la iglesia abierta hasta las nueue, y a esto mismo obligó las dos noches siguientes la extraordinaria deuoción del pueblo y la instancia con que lo pedían. Estaua la iglesia estas noches con muchas luces de hachas ${ }^{9}$ de cera, velas y lámparas pendientes del techo por todo el cuerpo de la iglesia: vuo la primera, luminarias en toda la ciudad, especialmente en las casas de el corregidor don Pedro de Córdoua Mexía, cauallero del hábito de Sanctiago, que mostró en esta//

\section{[Fol. 2]}

en esta ocasión no solo la grande puntualidad y orden que guarda en las cosas que toma entre manos, sino vn singular afecto a la religión de la Compañía de Jesús, y en todas las iglesias, conuentos y parochias, la gente que acudió particularmente los tres días primeros a la Compañía de noche y de día, asistiendo delante del altar del Beato Ignacio, fue como suele en tiempo de vn grande jubileo, velando algunas personas con hachas encendidas y el gran concurso que vuo obligó a que en la dicha iglesia de la Compañía, por toda la primera semana vuiesse música de muchos y diuersos instrumentos, también obligó esta deuoción común a que toda la semana vuiesse repique de campanas acompañado con chirimías, y esto se continuaua desde el amanecer hasta dos horas de noche, para lo qual se juntaron de los pueblos circunuezinos ocho 
o diez ternos de chirimías que puestos en diferentes partes se correspondían y con esto se entretuuo la primera semana.

Para la segunda traçaron las religiones entre sí de celebrar la octaua del sancto y solo la de Santo Domingo se ofrecía a celebrarla toda con el gasto de la cera, y otras cosas necessarias. Instó en esto el corregidor queriendo juntamente con las demás religiones celebrar esta octaua, más por razones particulares que los padres de la Compañía dieron fe, dexó quedando satisfecho su merced y todas las sagradas religiones y rendidas las gracias de parte de la Compañía y así traçó otra fiesta para el domingo siguiente del modo que se sigue. El sábado víspera del quarto domingo después de Pascua vuo vnas vísperas soleníssimas en la Compañía, con asistencia del corregidor y cabildo, y de todas las religiones. Acabadas las vísperas se oraron dos oraciones, vna en latín y otra en romance, que oró vn hijo estudiante del corregidor, haziéndole para solo este acto vn rico y costoso vestido. Aquella noche como lo tenía tracado el dicho corregidor Don Pedro de Córdoua Messía y los demás caualleros salieron por toda la ciudad sin quedar alguno de quenta muy galanes, con vestidos muy costosos y de color con hachas, passeando toda la ciudad en orden de máscara ${ }^{10} \mathrm{y}$ corriendo en los sitios más acomodados llegaron a la Compañía y si ser posible resistir la entrada al patio corrieron en él muchos lances ${ }^{11} \mathrm{y}$ hizieron el caracol ${ }^{12}$, aclamando santo Ignacio, santo Ignacio con grande regozijo y vozes, y demonstración del [sic] alegría y gusto con que hazían aquella fiesto [sic]. Boluieron a dar otras vueltas por el lugar, y a las nueue dexando los cauallos a las puertas de la iglesia de la Compañía, se fueron por ella al altar del Beato Padre Ignacio, y dexaron en él las hachas para que ardiesen en honra suya, esta misma noche bien alegre y regozijada por lo dicho lo fue más con muchas inuenciones de fuegos, cohetes y otras cosas deste género. Esto passó la víspera del día de la missa y antes de venir a él se dirá el adorno que tuuo la iglesia de la Compañía estaua toda la capilla mayor de terciopelos y damascos carmesíes con flocaduras de oro y debaxo de vnos quadros grandes de linda mano estauan otros menores al vn lado de apóstoles y al otro de sanctos y a los dos los mártyres de la Compañía. Todos estos terciopelos y damascos estauan cubiertos con laços de tocas ricas, y a los lados y en los blancos láminas pequeñas y agnns [sic] grandes guarnecidos. Finalmente fuera grande prolixidad el contar en particular el rico adorno del altar mayor la multitud de relicarios, láminas, ramilletes, fragancia de olores, caçoletas, ${ }^{13}$ peuetes, ${ }^{14}$ pastillas, e que todo parecía vn pedaço del paraíso. Estaua en medio de la capilla mayor la imagen del sancto en vnas ricas andas de plata tan llenas de cadenas de oro y joyas que estas y las que el sancto tenía se apreciaua en veinte mil pesos. Adereçada pues assi la iglesia el quarto domingo de Pascua dos horas antes de amanecer començó a sonar de la torre de la Comp[añía] música de varios instrumentos que fue buena aluorada para la ciudad. Cantó la missa el padre Juán Vázquez rector de la Comp[añía] y a ella se halló el corregidor con su cabildo y todas las religiones y caualleros del pueblo. El sermón predicó el padre Hernando de Aguilera de la misma Comp[añía] muy buen predicador y fue bien estudiado, assí para lo que auia de decir como para lo que la modestia le obligaua a callar, y en él dio las gracias a la ciudad y religiones por el grande afecto que a su religión auian mostrado en esta ocasión. Acabado este officio de missa y sermón salió la procesión alrededor de toda la plaça que estaua muy bien colgada. Estauan a trechos algunos altares y a la puerta de la compañía vno con grande adorno y riqueça lleuáronle las andas del sancto en la procesión que se hizo con grande solenidad, mucha música y luces, las más de hachas, gran concurso de gente, clerecía y religiosos y número sin número de indios que con los pendones//

\section{[Fol. 3]}

e insignias que de sus parochias y pueblos comarcanos auian traydo la acompañauan. Con esto se acabó por aquella mañana la fiesta.

A la tarde salieron muchos estudiantes con máscaras y libreas a regozijar el pueblo corriendo la plaça y calles adonde está la Compañía estaua puesto vn don peropalo $^{15} \mathrm{o}$ estafermo ${ }^{16}$. Eran estos estudiantes los hijos de los caualleros y vecinos del lugar, y sabían algo de aquel género, y así lucieron mucho las inuenciones y pareció muy bien su destreça en romper lanças y lo mismo hizieron el domingo siguiente a este con muchas más ventajas.

Ordenó el corregidor para el miércoles y jueues de esta segunda semana (que se ha mostrado con grande estremo afecto al bienaventurado Ignacio y su religión) vnas cañas ${ }^{17} \mathrm{y}$ toros, ${ }^{18} \mathrm{y}$ otras inuenciones y salió todo lo mejor que después que el Cuzco se fundó se ha visto, vistosas y costosas libreas, lindos cauallos luego muy 
concertado, brauos toros y con ser esto tal lo que más le estimó fue ver que nadie se escusó de entrar en el juego. Hiziéronse estas fiestas en la plaça de la ciudad, jugó cañas el corregidor que lo haze raras vezes aunque lo sabe hacer con gran destreça y agilidad y en esta ocasión fue muy singular la que tuuo fueron las quadrillas de a ocho y pudieran serlo [roto] todo en la corte. Antes que entraran por la plaça vinieron en orden de passeo por la Compañía, pasando por la puerta principal y haciendo reuerencia al santo en cuya honra se hazía la fiesta. No succedió desgracia ninguna de los toros y estimóse mucho por ser de los mejores que en el Cuzco se han corrido. Acabado el juego de cañas tornaron todos los caualleros a la Compañía dando gracias al sancto por no auerles sucedido ninguna desgracia, mostrando en todo su nobleza y deuoción.

El día siguiente fueron las fiestas en la plaça de la Compañía ${ }^{19}$ [roto] que es más capaz que la del cabildo para lo qual se rompió con mil dificultades que allanó la deuoción. Cercóse toda que no fue la menor dificultad por ser las calles muy abiertas, corriéronse los toros y lo particular que se puede decir es que se esmeraron los caualleros en salir galanes y sacar jaezes ${ }^{20}$ costosos. E fueron muy de ver algunas inuenciones con que se corrieron los toros, particularmente la de vn toro encohetado, y lleno de machinas de fuego en las hastas, salió a la plaça, barrió la gente y fueron de ver los saltos que le hazía dar el fuego, que duró un quarto de hora el acabarse. Fue de gusto el ver los lances que el toro hizo después quando se le atreuían, entendiendo que estaua casi muerto, porque bolteó a muchos sin hacer daño a nadie. Vuo vna buena lançada y otras cosas de recreación y gusto.

El domingo siguiente que fue el quinto después de Pascua, celebraron la fiesta los vizcaynos, reparando poco en mucho gasto tuuieron el sábado antes chirimías a ternos en la torre de la Compañía hasta las nueve de la noche y ante su puerta hizieron vn castillo en que pusieron vna gran rueda de póluora, y antes de darle fuego ardían vnas grandes ollas de pez y resina con que auía gran claridad a que correspondía la de la iglesia llena de luminarias en que gastaron estos señores vna barra. Auía gran gente y regocijóse gran parte de la noche con cohetes y otras inuenciones de pólura y rematóse con la rueda que duró grande espacio y al tiempo que ardía se tocaron varios instrumentos.

El día siguiente dixo la missa el padre rector de la Compañía, y predicó el padre fray Benito de la Huerta provincial de san Francisco. Fue el sermón muy docto y con mucho espíritu y trató de las virtudes del sauto [sic] con grande gusto de todo el pueblo. Celebróse esta fiesta con la misma solenidad y adorno de la iglesia que la pasada.

Acabada la missa vuo otra solene procesión por un breue espacio de la plaça y al pasar las andas (que lleuauan los padres de San Francisco) por el castillo, se dispararon algunas rociadas de arcabuzes y mosquetes, y particularmente algunos versos ${ }^{21}$ y esmeriles ${ }^{22}$ que dio bien que ver y con esto se concluyeron las fiestas de españoles mostrándose en ellas don Pedro de Córdoua Messía corregidor del Cuzco tan grande cauallero y deuoto al santo que quando los caualleros desta ciudad (que todos se señalaron en esto) no vuieran acudida tan noblemente bastaua ver su zelo y puntualidad en todo para no faltar en alguna cosa de lo que se ha dicho. //

[Fol. 4]

Relación de las fiestas de los indios.

Animados los naturales desta ciudad con lo que auían visto en los españoles y desseosos de acudir a pagar en algo la voluntad conque los padres de la Compañía les acuden y también desseosos de cumplir la del corregidor, hizieron vnas soleníssimas fiestas y dexando (por ser sabido) el número destos indios que es de treinta mil sin niños y mujeres y la más calificada gente de todo este reyno, por ser este el asiento de los Ingas en quienes ha quedado la memoria de las cosas más memorables, començaré las fiestas por las espirituales a que dieron principio el lunes del quarto domingo de Pascua.

Concertáronse las seis parochias desta ciudad y dos de fuera della ${ }^{23}$ para venir por su antigüedad cada vna a la iglesia de la Compañía de Jesús en procesión y tener en ella missa cantada y sermón con lo demás que se dirá. Lo común en estas procesiones fue venir por medio de la ciudad con muchas cruzes, pendondes, danças, música y muy galanes los indios principales, y al fin de la procesión el cura de la parochia y el cacique principal trahían differentes inuencio[nes] con que se tirauan la gente. Celebráuase la missa a las diez a canto de órgano y con diuersos instrumentos de música y se les predicaua en su lengua.

Lo particular fue que el lunes dicho vino la parochia de Bethlen, ilustrando la procesión todos los Ingas della, nietos y descendientes de los atuncuzcos y muy galanes. Recibióse en la Compañía con repique de campanas y 
música. El martes vino la parochia de Sanctiago cantando el golpe de la gente canciones en loor del sancto. Venían muy vistosos a su vsança y cantauan vnas chançonetas de cierta aue negra llamada curiquenque ${ }^{24}$ preciada entre ellos [roto] color y propiedades buenas al sancto y hábito de su religión. Entró el miércoles la parochia del Hospital de los naturales, con grande estruendo de danças y música e haciendo vn regozijo que se vsaua en tiempo del Inga Huaynacapac mudado a lo diuino en loor del sancto. Esta procesión recibió la cofradía de Jesús que está en la Compañía, sacando su niño Jesús en hábito de Inga, ricamente adereçado y con muchas luces. Viernes acudió la parochia de san Christóual, adonde están reducidas dos casas illustres de Ingas. Vinieron con gran magestad y vista de la música y demás aparato lleuaron algunas danças muy vistosas. Sábado entró la parochia de san Blas en que venían dos Reyes Ingas. Lleuauan delante cierta invuención que significaua vna victoria que sus antepassados ganaron en vna insigne batalla, aplicando en canto al sancto las aclamaciones que hizieron al capitán general que consiguió aquella victoria, acompañando esto caxas, clarines y otros instrumentos bélicos. El domingo que fue el día de la fiesta de los vizcaynos vino la parochia de santa Anna poco antes de la missa mayor. Entró la procesión por la plaça que estaua llena de españoles. Metió delante trezientos soldados cañares, armados de picas, alabardas y muchos arcabuzes, y muy bien vestidos sitiaron en la plaça un castillo que trahían. Combatiéronlo haciendo sus estacamuças al son de las caxas. No entró la procesión en la iglesia por estar llena de españoles y ser estos más de cinco mil indios y así se les predicó en la plaça. El lunes vinieron los del pueblo de san Sebastián, que está a media legua desta ciudad y esforçáronse a hacer una solene fiesta por la competencia común. Hizieron vna muy buena procession llena de bultos de sanctos en sus andas, pendones, etc., $y$ al fin della sus dos caciques principales descendientes de Ingas lleuauan delante quatro hombres de armas vestidos de colorado con vnas hastas de plumería en que yuan las armas de los dos caciques que eran la borla del Inga y dos culebras con vn castillo. Vuo mucho que ver en esta procesión por la diuersidad de danças e inuenciones. Rematóse con su missa y sermón que se acabó a la vna de la tarde, entreteniendo el resto della a toda la ciudad con sus danças y cantares, etc. La vltima procesión fue del pueblo de san Gerónimo, que está legua y media del Cuzco y fue buen remate de todas las passadas por la mucha gente principal que trahía de ingas con las insignias de águilas y coronas del Inga venían representando la victoria que sus passados alcançaron siendo pocos de los chancas que eran veinte mil aplicando el canto de la victoria el beato Ignacio. Esto es lo tocante a las fiestas espirituales, dexando las muchas coufessiones [sic] y comuniones que en ellas vuo, por venir a las que los indios hizieron en la plaza de la Compañía. //

\section{[Fol. 5]}

Fueron estas fiestas tales que no se sabrá hacer relación de modo que se forme el deuido concepto dellas por no auerse hecho otras semejantes en el Cuzco. El día de la Ascensión por la tarde asistiendo a este regozijo el corregidor y caualleros de la ciudad y más de diez mil almas entre españoles e indios que llaman yanaconas, de número de más de mil, bien adereçados y vestidos en hileras de quatro en quatro con su capitán alférez y sargento y con muchas cadenas de oro, perlas, bordados y pedrería, con diuersos géneros de armas y dauan sus rociadas a trechos, dieron vuelta a la plaça en la qual se hizo vn esquadrón. Vióse vn indio muy costosamente vestido con vna pica arbolada en el estremo de ella vn estandarte con las armas de España y tocándose las caxas hizieron vna escaramuça que dio grandísimo gusto por no esperarse tanto orden de gente en cosa que no auían exercitado, siguiéndose a esto vnos alcanciaços a manera de juego de cañas que dio mucho que ver y entretuuo toda la tarde junto con la música de chirimías, etc.

Las fiestas que el domingo siguiente después de la ascensión se hizieron se auentajaron a estas. Salieron en primer lugar quatrocientos indios cañares (que como se dixo arriba era la guarda del Inga) muy bien adereçados en forma de esquadrón con sus capitanes. Yuan vizarros, con turbantes, chipanas, ajorcas de plata, ${ }^{25}$ canipos $^{26}$ también de plat[a] que son a figura de luna con las armas que ellos vsauan y las que nosotros vsamos, espadas, picas, arcabuzes, etc. Hizieron su entrada con grande aparato de guerra, como los passados que diximos. Entraron tras ellos otros dozientos indios también cañares, y los canas de Ancocaua ${ }^{27}$ vestidos a su trage antiguo con ondas en las manos haziendo demonstración de que tirauan con ellas, turbantes adornados con hilo de plata y canipos resplandores o rayos de oro llamados en su lengua purapura, que es encomienda o diuisa de nobleça que solía dar el Inga por seruicios de la guerra. Dieron estos también buelta por la plaça, respresentauan estos dos campos las batallas que antiguamente tuuieron entre 
sí los cañares a los canas. Començaron la batalla que duró buen rato tocando los instrumentos bélicos y al fin venzidos los canas fueron presos y traídos al corregidor cantando victoria porque reducidos los canas a la corona del Inga le ayudaron en sus conquistas valerosamente. Sacaron este día las insignias que se ha dicho se dauan a los soldados valerosos.

Siguióse a esta otra fiesta que dio más gusto a los españoles por auerse introducido en ella once ingas deste reyno y ser toda la demonstración que se podía hazer de regozijo reyes del Pirú fueron onze 1. Topacinchipoca, 2. Mancocapac, 3. Capaclloquiiupangui, 4. Incarocac, 5. Maitacapac, 6. Apusitinca, 7. Yauariuacac [sic], 8. Biracochainca, 9. Pachacuti, 10. Topainca, 11. Vainacapac, salieron representando estos reyes los más cercanos de sus desencientes. Venían en sus literas las más cubiertas de plumas de diuersos colores y las lleuan hombros de indios. Yuan assentados con mucha magestad (que fue lo que más se les aduirtió en este acto) y al passar hazían su cortesía al corregidor y demás caualleros inclinando solo algún tanto la cabeça a que respondían el corregidor y demás caualleros quitando las gorras que pareció muy bien. Venían vestidos al trage inca de cumbis ricos que es su brocado dellos, con cetros reales en las manos y vn principal al lado con vn quitasol de pluma lleuaua cada vno sus insignias reales gente de guardia lucida y vestida a su trage y estos eran los descendientes de aquel Rey. Yuan entre la infantería (que sería de más de mil indios) dando buelta a la plaça y por capitán de todos, don Alonso Topaatauchi tío de don Melchor Inca, que aora está en la corte y fue el que se auentajó en yr más galán y vizarro. Yua muy acompañado y lleuaua a su lado quatro capitanes y los Ingas dichos veían en sus tronos a trechos y por su orden, siendo el vltimo el primero rey Inca que vuo en este reyno y el primero del Cuzco el inca Vaynacapac a quien alcançaron los primeros conquistadores. Sería alargar mucho estar relación si se vuiessen de poner en particular las insignias y diuisas conforme a las conquistas y proeças de cada Rey, pero con todo esso el primero lleuaua por adorno de su gente de guarda vnos mazos de plumages redondos que ellos nombran purupuru respresentando el glouo del mundo y que este primer Inca lo auía conquistado, y a este modo yuan los demás Reyes con sus blasones harto arrogantes. Junta toda esta infantería en mitad de la plaça començaron a ganar vn castillo que estaua en ella cercado de vna laguna llamada yahuarchocha, ${ }^{28}$ esto es laguna de sangre// [fol. 6]

en memoria de la gran mortandad que el Inca Vaynacapac hizo en la conquista de los cananapes de Quito que fue tal que se llenó de sangre vna laguna ya por los muertos ya por auer lauado las armas en ella los soldados del Inca que fueron cinquenta mil, y se detuuieron en salir desta ciudad saliendo cada día tres compañías tres meses, vencieron el castillo y traxeron a los castellanos pressos al corregidor y algunos con cadenas de oro en lugar de hierros salieron con orden de la plaça y assí se acabó este día la fiesta y antes de venir a la vltima en que se dio fin a estos regozijos es bien dezir que el que en gran parte los solicitó a pedimento de los indios fue el juez de los naturales, que es un cauallero vezino encomendero del Cuzco, que mostró su grande affecto a las cosas del sancto y su religión y se halló en todas las fiestas tan galán cauallero que pudiera parecer en la corte, mudando galas, mochilas y cauallos cada día y sacó dos jaezes de chapería de plata costosíssimos y vistosos.

El miércoles siguiente fue el vltimo de las fiestas y celebráronle los indios de san Gerónymo. Halláronse en la plaça veinte mil almas y las ventanas con grande adorno y en ellas las señoras del lugar y muchos caualleros eu [sic] la plaça el corregidor con su cabildo en la puerta de la Compañía en vn cerrillo que está a vn lado de la plaça vn bosque y en vna gr[an] sierpe llamada Llactayoc $^{29}$ que fue en siglos passados dañosíssima a los Ingas porque mató muchos dellos en la conquista de los Andes. A otro lado de la plaça se hizo un castillo para lo que después se dirá. Entraron a las dos de la tarde estos Ingas de san Gerónymo en el quadrón formado con sus caxas, clarines y otros instrumentos ricamente vestidos y con muchas armas. Trahían por capitán estos que eran quatrocientos soldados al cacique principal del dicho pueblo. Lleuaua en la rodela vn león por diuisa con otras que hazían alusión a las armas de sus passados, delante del qual yua vn principal con su honda, diziendo en voz alta aquí vienen los señores Ingas de tal parte a mostrar su grandeça. Yua también casi en aquel paraje otro soldado que lleuaua vn yelmo con que el Inga rey entraua en las batallas y por successión le heredauan sus descendientes. Venía por el alferez la segunda persona del cacique principal vestido de seda de colores y en los hombros dos leones de plata y en el calçado otros dos. Venían en la retaguarda dos Incas reyes de donde estos descendían con la magestad que le dixo de los de arriba particularizándose estos en dos collares ricos y por orla [sic] el vno mucho número de dientes que 
por memoria auía quitado a los capitanes de aquellas naciones que sus passados auían conquistado, y el otro varios dientes de leones, ossos, tigres y otros animales fieros que también sus antepassados auían desquijarado y muerto, siendo en realidad de verdad los mesmos dientes de los indios y fieras venzidos. Llegando pues a emparejar con el corregidor y los demás que estauan con él, el vltimo Inca paró con su acompañamiento y dixo en breues palabras aunque con grande affecto el que él y los suyos tenían al beato padre Ignacio y a los padres de la Compañía y cómo esta fiesta la hazían en reuerencia del santo padre a quien los Incas en particular eran en obligación. Acabado el passo y entrada de los quatrocientos Incas salieron de traués como ciento y cinquenta de los mismos representando la gente belicosa de Chile armados como de punta en blanco de cierta vestidura que parecía coraças, llegauales hasta las espinillas y fue cosa tan peregrina que admiró y dio notable contento porque significaua grande fierea y salieron vniformes todos, lleuauan vnas grandes maças en las manos casi del género que la piel o vestidura hizieron dos campos representando la batalla, el Mapocho chileno que es hasta donde llegó el Inca, esto es hasta Santiago de Chile sin poderlos conquistar más. Representada pues la batalla acometieron los vnos a los otros con mucho orden y concierto escaramuzando sin hazerse ventaja en gran tiempo. Al fin los chilenos hizieron demonstración de verse apurados y assí retiraron su esquadrón al cerrillo que se dixo, desfendiéndose valerosamente y acometiéndoles mas se hallaron apurados y obligados a retirarse al castillo. Combatiólo el Inga y rindiólo y prendió a los cercados y aprisionólos entregándolos a sus capitanes que se passeauan con ellos por toda la plaça. Quemáronles las casserías del cerrillo, cuyo incendio representó al viuo lo que suele succeder en semejantes ocasiones. Duró esta fiesta hasta las quatro. Siguiéronse vnos toros y muchos caualleros en la plaça, y grandíssimo número de indios, que como era la fiesta suya se quisiereon mostrar más animosos en hazer lances de que escaparon sin daño//

\section{[Fol. 7]}

Entre algunas cosas que passaron de gusto es digna de saber vna que fue auerse atreuido vn indio a dar vna lançada. Salió a la gineta bien vestido, púsose en sitio cómodo con gran denuedo y admiración. No le acometió el toro, retiróle el juez de los naturales pareciéndole que auía hecho harto, mas después incitado con la brabeça de vn toro que salió y hizo lances en algunos tornó a salir él a hazerle en el toro. Aguardóle sin turbarse. Acometióle, dio su lançada y metióle dos varas de lança en el cuerpo, donde se quebró. El toro auía entrado muy apriessa y assí mató al cauallo y echó el cauallero en tierra. Acudiéronle los españoles a tiempo y acabaron de matar el toro. Tomó otro cauallo el indio y passeó la plaça, recibiendo mil parabienes que se le dauan con gusto, por auer sido este hecho raro y vnico en esta gente con lo qual se acabaron las fiestas auiendo durado veinte y cinco días que se quentan desde el dos de mayo hasta veinte y seis del confirmándose con ellas la deuoción al bienauenturado padre Ignacio, al qual trató la ciudad tomar por abogado del tabarsillo que en aquella ciudad es muy grande y con voto se obligó el cabildo caualleros y todos los indios de acudir cada año a su casa y celebrar su fiesta con la solenidad possible y su deuoción es tanta que con auer sido estas fiestas tan cumplidas les parece auer quedado cortos en celebrar al patrón de religión que tanto bien haze a la república los padres de la Compañía reconocidos a lo que se auía hecho dieron las gracias al corregidor, como al principal autor de todo esto y al cauildo y otros caualleros.

Con licencia, impressa en Lima en casa de Francisco del Canto. Año de 1610.

\section{El contenido de la Relación}

Los primeros días de celebración muestran una evidente y esperable participación de las castas criollas y españolas del Cuzco en una programación que difícilmente permitía a la ciudad desarrollar cualquier otra actividad que no fuesen estas fiestas. Las misas y prédicas (en español y latín para españoles y criollos, y en quechua para los indígenas), sermones, música, danzas y representaciones colmaban los días desde el alba hasta la noche. Durante más de 3 semanas la ciudad recibió a millares de visitantes de los alrededores, además de ver por las calles numerosas procesiones acompañadas de caballos y corridas de toro mientras que las iglesias y parroquias no daban tregua a sus campanarios, solo interrumpidos por los disparos producidos por las entretenciones. Entre las castas participantes destacan los españoles, criollos, vizcaínos, cañares, hatun cuzcos, canas, chancas e incas, obviamente. Maravillosos trajes y atavíos, adornos y telas de variados colores se encargaban de solazar la vista de los espectadores mientras que las diversas procesiones se acompañaban de instrumentos musicales como las chirimías, cajas, clarines y órganos para las misas 
cantadas. La quema de distintos tipos de perfumerías e inciensos se encargaba de saturar el aire.

Son muchos los aspectos a profundizar, sin embargo, por motivos de espacio nos referiremos solo a algunos de ellos: la cofradía del Niño Jesús, el escudo de armas de Guayna Cápac y, finalmente, la procesión de las memorias dinásticas incaicas.

\section{La cofradía del Niño Jesús y el escudo de armas. Apropiaciones visuales para nuevos escenarios}

Esta fue una de las primeras cofradías jesuitas del Cuzco y corresponde a una de las estrategias más utilizadas por la orden jesuita en la evangelización de los indígenas. Mateos (1944 [1600]: 39) señala que

\begin{abstract}
Finalmente, una cuarta manera usaban de misión continua con los indios de las ciudades, cultivándolos espiritualmente con las congregaciones o cofradías que establecían entre ellos; una de las primeras cosas que hacían al fundar algún colegio era establecer la Cofradía del Niño Jesús para los indios, donde estos pobres hallaban abundante pasto de instrucción religiosa, tenían sus fiestas y procesiones con gran esplendor y hallaban también socorro en sus enfermedades y otras necesidades temporales que les ocurrían.
\end{abstract}

$\mathrm{Al}$ respecto, Valenzuela aporta que la creación de la cofradía del Niño Jesús ocurre en un momento en que "la evangelización jesuita coincidía con las directrices pastorales de la Contrarreforma, el Concilio de Trento (1545-1563) y el Segundo Concilio Limense (1567). Además, fue contemporánea al arribo del virrey del Perú, Francisco de Toledo (1570-1581), y al inicio de su proceso de reforma y control del territorio y sus habitantes" (Valenzuela 2006: 491-492).

Esta cofradía fue fundada en la capilla adjunta a la iglesia de la Compañía por Jerónimo de Portillo, primer provincial jesuita, sin embargo, sería Gregorio Cisneros quien la difundió por el obispado del Cuzco. Llegado un momento en el siglo XVII, llegó a tener más de 500 cófrades indígenas "y a los ciento cincuenta indios nobles pertenecientes al grupo de los asíllamados "veinticuatro"; los descendientes directos de los doce ayllus o panacas reales de los incas" (Mujica 2016: 64). Hacia finales del siglo xvir llegaron a existir más de 30 cofradías del Niño Jesús en el obispado del Cuzco, tal como consta en los informes encargados por el obispo Manuel de Mollinedo (Martínez 2013: 2014). Empero, el culto a la imagen devocional del Niño Jesús Inca encontró en la figura del mismo Mollinedo su principal detractor, quien ordenó la prohibición y retiro de todas las imágenes del Niño Jesún Inca de las iglesias de su arquidiósesis (Bradley \& Cahill 2000: 118). Por lo tanto, es muy probable que el apogeo de este culto haya llegado a su fin hacia finales del siglo XvII, ${ }^{30}$ aunque incluso llegó a traspasar las fronteras cuzqueñas llegando hasta Lima, tal como se atestigua en la Relación de 1610, y Potosí (Mujica 2016).

En la crónica de Mateos (1944 [1600]) se relata que cuando sacaban en procesión al Niño Jesús para las fiestas de Corpus Christi era "la cosa más lustre que ay en esta ciudad, pues salía la aristocracia indígena con él andando sobre los hombros, encabezada por un Inca principal, ricamente vestido, con una capa escarlata y en la mano el pendón real en vara de plata con las insignias del Nombre de Jesús. Éstos eran seguidos por los cantores y ministriles de la cofradía que tocaban orlos, chirimías, trompetas y flautas, llevando cera encendida por valor de doce mil ducados" (Mateos 1944 [1600], II: 35-38).

Las pinturas coloniales que muestran al Niño Jesús Inca lo hacen en su advocación de Salvador del Mundo (Mujica 2016: 61) vistiendo un atuendo que manifiesta los complejos procesos de sincretismo cultural postconquista (fig. 4 a y b) y permitiéndonos pensar que su presencia en festividades como esta y el Corpus Christi, por ejemplo, reactualizaba, entre otras cosas, memorias incaicas. En las figuras $4 \mathrm{a}$ y b es posible ver una serie de atributos visuales que corresponden a la cultura incaica: la primera imagen nos muestra un Niño Jesús con un llautu (suerte de cintillo hecho con pelo de vicuña) que presenta el torreón del Cuzco y la borla dorada sobre la frente. Calza sandalias con cabezas de felino. El niño Jesús de Huanca viste un traje con bordados de kantutas y toqapus, mientras que sobre su espalda cae una capa sujeta por dos cabezas de felino, las mismas que aparecen en su calzado y rodillas. Gobierna el tocado una pluma de corequenque, y sobre su frente está la mascapaycha.

En cuanto al escudo de armas, en el texto se señala que "dos caciques principales descendientes de Ingas lleuauan delante quatro hombres de armas vestidos de colorado con vnas hastas de plumería en que yuan las armas de los dos caciques que eran la borla del Inga y dos culebras con vn castillo". Recordemos que según la bula papal se autorizaba a los descendientes de Huayna Cápaq el siguiente escudo: 

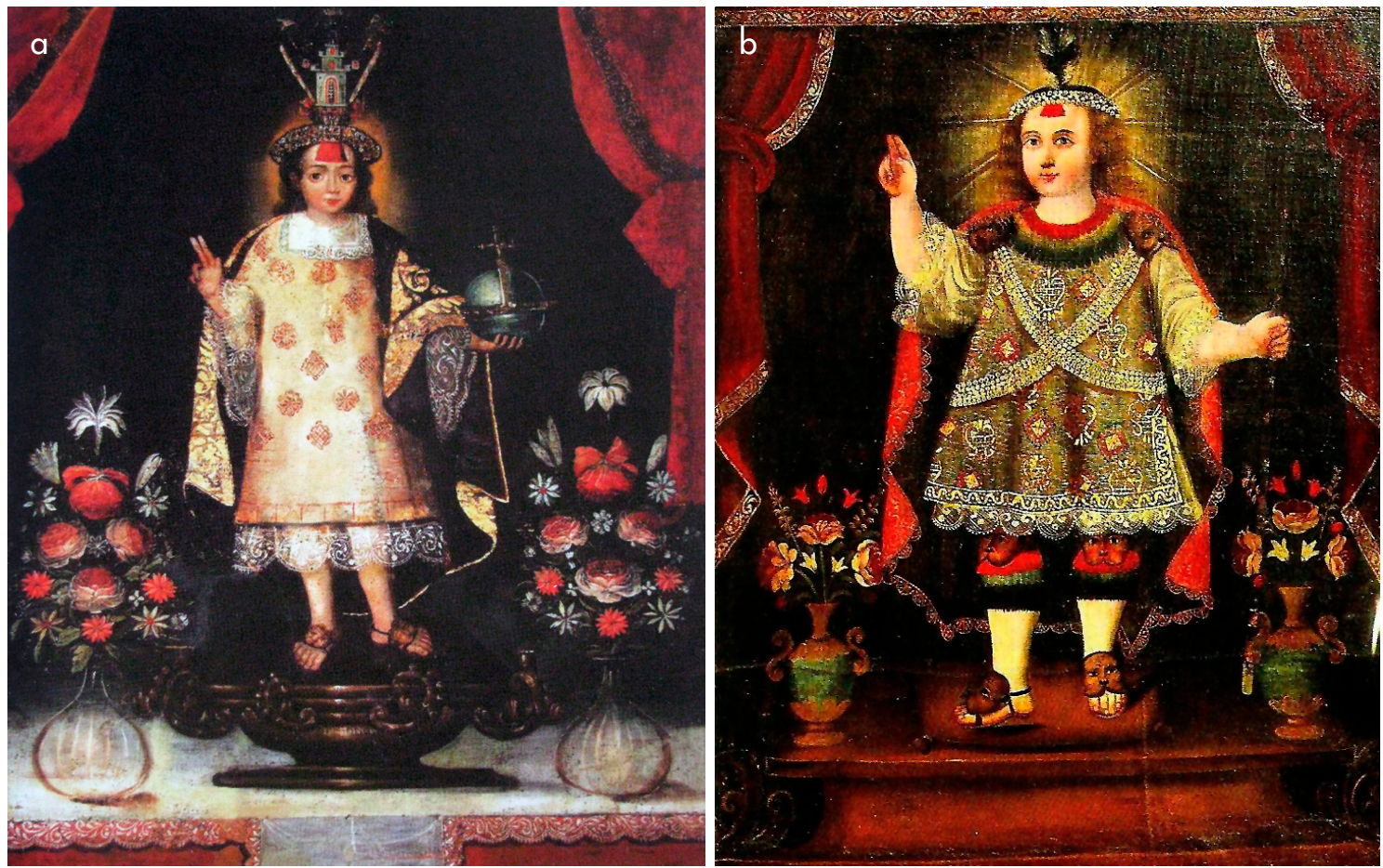

Figura 4: a) Lienzo del Niño Jesús Inca (Iglesia de la Compañía de Jesús, Cuzco); b) Lienzo del Niño Jesús Huanca Inca (Estenssoro 2005 : 140). Figure 4: a) Inca Infant Jesus painting (Society of Jesus Church, Cuzco); b) Huanca Inca Infant Jesus painting (Estenssoro 2005: 140).

hijos legítimos de Guaynacapac y nietos pr[inci]pales del gran Tupo Inca Inpanqui [Yupanqui], Reyes y Señores N. que fueron destos dilatados Reynos y Provincias del Perú: Un escudo fecho dos partes que en la una dellas esté un Águila Real en campo rosado y a los lados leones reales que cojan arco iris y encima una borla carmesí que solían tener por amarita y a los dos lados culebras coronadas en campo rosado. Y por la una letra que dice, Ave María en el medio y en el otro lado un castillo en campo amarillo y por divisa un águila real con sus trabales dependencias afollajes de azul engarzadas en ellos cuarenta y dos coronas imperiales alrededor con otras tantas reales que son la una parte de las coronas que dichos señores Reyes naturales de esos dichos Reynos y Provincias del Perú tuvieron sugetos a su Dominio y Corona. Y asimismo vos señalamos y damos y concedemos por Toisón propio para que le traigáis puesto a el pecho: un mascarón de oro que le cokan por doce pares de culebras coronadas y estas asidas unas de otras formando lazos y eslabones [...] (Cédula Real, Valladolid, 9 de mayo 1545 en Pardo de Guevara y Valdés 2005: 397).

Finalmente, el escudo adoptó la forma que se aprecia en la fig. 5.

\section{Sobre la procesión y la memoria que se canta y que se baila}

En los primeros relatos de la conquista, bajo la pluma de Miguel de Estete (1533), uno de los soldados que acompañó a Francisco Pizarro en el encuentro con Atahualpa en Cajamarca, encontramos una de las más tempranas referencias coloniales sobre las representaciones que son narradas en esta Relación. Cuenta Estete que recién retornadas al Cuzco las huestes almagristas acompañadas por los incas, se decidió hacer una gran fiesta a la cual los indios llevaron a todos sus abuelos y muertos (momias) a la plaza, procesión que encabezaba el Inca y su padre Guayna Cápaq. Una vez que se ubicaban todas las momias en su correspondiente lugar en la plaza, se entonaban sus cantares, donde se relataba lo que cada uno de ellos había hecho y conquistado (Estete 1533). Algunos años después, con motivo de la llegada del virrey Toledo, se realizaron varias fiestas y corridas de toro:

[...] por dar lugar a la fiesta y regocijo de los indios, que no menos voluntad tenían de mostrar la suya en este recibimiento [...] delante venían los ingas, a quien seguían las provincias de los cuatro suyos, cada una con su bandera 


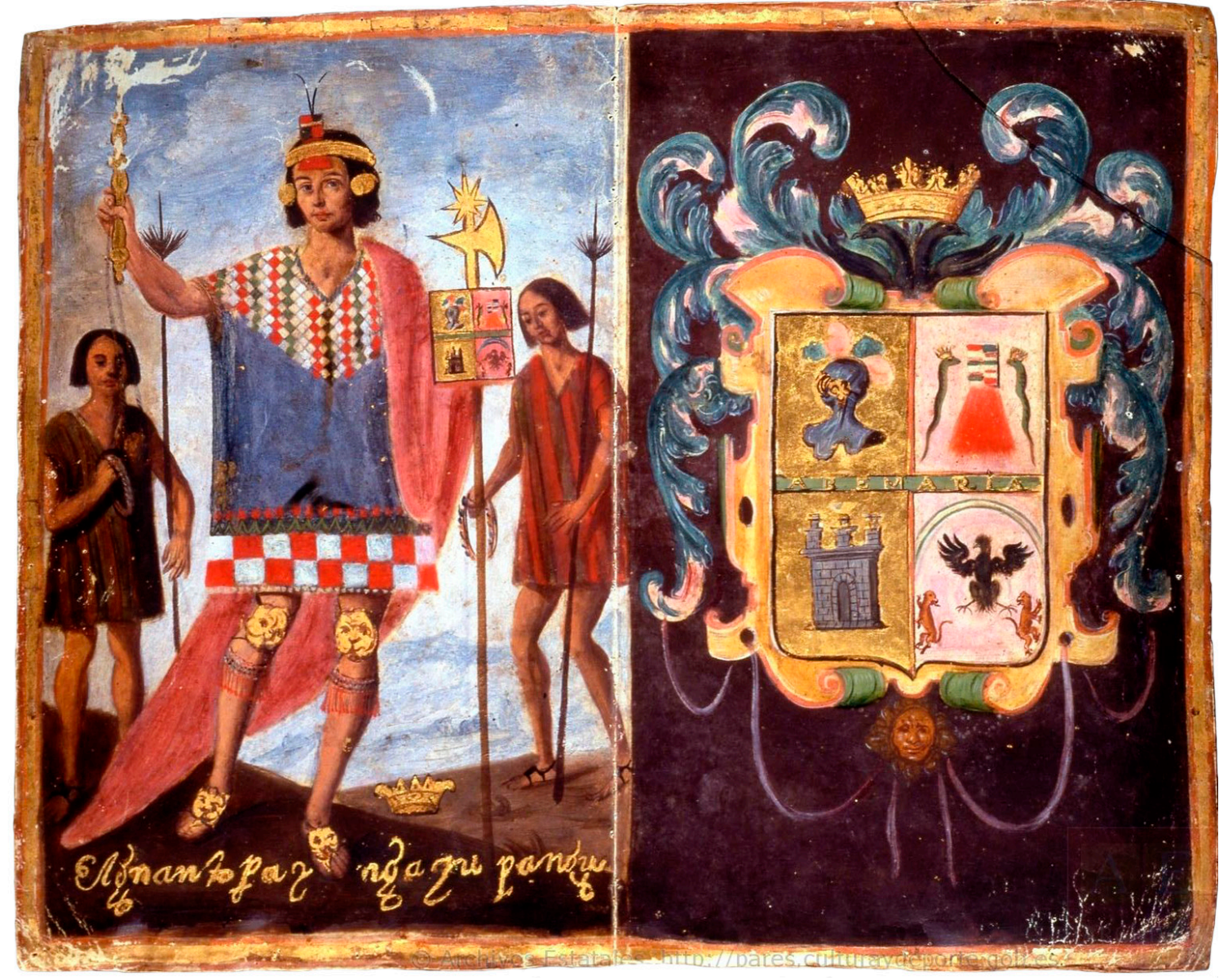

Figura 5. Escudo de armas concedido por el emperador Carlos v a los descendientes de los incas Gonzalo Uchu Hualpa y Felipe Topa Inga Yupanqui, hijos de Huaina Capac y nietos de Tupa Inga Yupangui (Archivo General de Indias, Mapas y Planos-Escudos, 78). Figure 5. Coat of arms granted by Emperor Carlos V to the descendents of Inca Gonzalo Uchu Hualpa and Inca Felipe Topa Inga Yupanqui, sons of Huaina Capac and grandsons of Tupa Inga Yupangui (General Archive of the Indies, Maps and Plans-Coats of Arms, 78).

y gran número de pendones de diversidad de colores, $\mathrm{y}$ los más o casi todos los indios, con patenas de oro unos, $\mathrm{y}$ otros de plata en los pechos; $y$ chipanas de la misma suerte y canipos en las cabezas, y gran suma de plumería, [...] La entrada fue por la mañana [...] Los primeros fueron los indios, los cuales salieron hasta do llaman la Guasavara, que fue donde los capitanes del inga Atagualpa dieron la batalla al inga Guascar y le prendieron; y donde el capitán Quizquiz y otros salieron a darla al adelantado D. Francisco Pizarro (Torres 1867, tomo VIII: 253).

Como podemos ver, la representación hecha frente a Toledo tiene bastantes similitudes con las de la Relación. Una revisión de las fuentes documentales del siglo XVI nos permite postular que estas representaciones se llevaban a cabo desde antes de la Conquista y se realizan hasta la actualidad (Martínez et al. 2018). Así, según
Betanzos, habría sido el Inka Pachacuti (Martínez et al. 2011) quien, a la muerte de su padre Viracocha, instauró este sistema de prácticas que aseguraba la mantención y transmisión de las memorias dinásticas del Tawantinsuyu. Culturalmente organizadas, dichas prácticas determinaban momentos de ejecución, modos de activación, temáticas a transmitir y especialistas en su producción (Betanzos 1555, Cieza 1967 [1554]: cap. XI, Hernández 2013: 143). Especialistas como quipucamayos guardaban y transmitían estas memorias a través de cantos y bailes, eran seleccionadas, debatidas y acordadas entre los más ancianos y su fin era, como explica Cieza "se cantasen para que por ellos se animase la gente con los oír y entendiesen lo pasado en otros tiempos, sin lo inorar por entero". Según lo expresan Cieza de León y Betanzos, 
las memorias de los Inkas se configuraban, a través de los procedimientos antes descritos, una vez muerto el gobernante. Sabemos gracias a la descripción de un testigo ocular de los hechos de Cajamarca y la muerte de Atahuallpa, Pedro Pizarro, que a la muerte del Inka "quedaron dos hermanas que andauan haziendo grande llanto con atambores y cantando, contando las hazañas de su marido" (Pizarro 1986 [1572]: 69).

La presencia de representaciones memorias de linaje, tales como la que aparece en nuestra Relación, durante las festividades virreinales (religiosas o seculares) tiene tempranos antecedentes y una gran continuidad durante la colonia (Beyersdorff 1997; Husson 1998, 1999; Gisbert 2008). Nos referiremos aquí a cuatro de estas manifestaciones y que han sido bien documentadas para los siglos xvi y XVII, ${ }^{31}$ la más temprana en Potosí durante las fiestas realizadas en la villa en 1555 como celebración por la derrota del levantamiento de Francisco Hernández Girón y la nominación de los Santos Patronos de la villa (Arzáns 1965 [1735], Husson 1998). En las fiestas descritas por Bartolomé Arzáns de Orsúa y Vela en su obra Historia de la Villa imperial de Potosí, se representaron cuatro obras dramáticas sobre la historia incaica interpretadas por indígenas; la primera, Manco Cápaq, el origen de los monarcas Inkas y sus conquistas; la segunda sobre los triunfos de Huayna Cápaq; la tercera, Las tragedias de Cusi Huáscar, $12^{\circ}$ inga del Perú; y la última sobre la muerte de Atahuallpa. Contemporánea con la anterior, encontramos las ya referidas fiestas y procesión del Corpus Christi del Cuzco en 1555 relatada por el Inca Garcilaso de la Vega en su Historia General de Perú (Garcilaso 1962 [1617], Martínez 2008) la tercera, en las festividades realizadas en el Cuzco para celebrar la beatificación de Ignacio de Loyola en 1610 (Anónimo [1610], Cummins 2005) y, por último, en Potosí durante unas festividades en 1641 (Arzáns 1965 [1735], Gisbert 2008). En todas ellas aparece la nobleza indígena desfilando con toda pompa, personificando a los Incas prehispánicos, desarrollando representaciones del pasado, en especial las grandes conquistas llevadas a cabo por el Tawantinsuyu, tal como en nuestra Relación de 1610.

\section{CONCLUSIONES}

Nuestra propuesta es que las representaciones de linaje, como sistema de comunicación destinado a la conservación y transmisión de memorias de los inkas, continuaron desarrollándose en las celebraciones públicas a lo largo de la Colonia, tal como sucede en el caso de la Relación, transformándose en muchos casos para asegurar su permanencia, pero al mismo tiempo, siendo capaces de seguir enunciando una memoria colonial sobre el pasado incaico a través de cantos, danzas y la presencia de los inkas muertos encarnados en la nobleza indígena cuzqueña colonial. Asimismo, las fiestas y celebraciones virreinales se convirtieron en un espacio para desplegar discursos visuales, muchas veces discursos políticos como lo atestiguan los eventos ocurridos en el Corpus Christi de 1555 descrito por Garcilaso, que permitieron reclamar estatus dentro del cuadro de privilegios que había creado la corona para sus súbditos indios, así como para enviar mensajes a las dos Repúblicas.

Las escenificaciones hechas en honor a Ignacio de Loyola fueron ceremonias cargadas de representaciones sobre el pasado inca, incluso una de las parroquias de indios representó la derrota de los chancas en una canción (Cummins 2005), los cañaris y canas realizaron un tinku, pero también estuvo presente la conquista de Quito, Chile, entre otros episodios. Cabe recordar que, si bien se exaltaban los triunfos de los Incas, la elite indígena era cuidadosa en demostrar su sujeción a la corona y la motivación cristiana de tales representaciones. "Los combates terminaban con la victoria de los incas o sus aliados al tomar prisioneros a sus contendores. Luego los prisioneros eran presentados al corregidor, que estaba sentado en la plaza junto con otros dignatarios españoles. El botín de las pasadas victorias incaicas era entonces entregado simbólicamente a los nuevos gobernantes" (Cummins 2005: 38). A esto se suma también el hecho de que en la genealogía incaica presentada en esta festividad, cuidadosamente los nobles descendientes de los Incas solo se refirieron hasta Guayna Cápaq, dejando fuera todo el conflicto entre Huáscar Inca y Atahuallpa, Manco Inca y Túpaq Amaru I. Parte de esta puesta en escena simbólica se reafirmó visualmente en el uso del escudo otorgado a los descendientes de Guayna Cápaq. ${ }^{32}$ La integración y participación de las élites indígenas en este tipo de festividades necesariamente ubica esta problemática en un contexto de negociaciones de un poder colonial que es "reconocido" pero a la vez resignificado 
y ubicándolo en un eje histórico tremendamente tenaz y versátil que se acomodó a distintas circunstancias para su subsistencia y reactualización.

\section{NOTAS}

${ }^{1}$ Ya en 1544, a solo diez años de la fundación de la Compañía, Doña Juana de Habsburgo había donado 500 ducados para que se fundara un colegio en el Virreinato del Perú y que, posteriormente, estaría en manos de esta orden religiosa. "Finalmente, el año siguiente de 1566 y con fecha 3 de marzo, escribió el mismo Rey una cédula a San Francisco de Borja, entonces General de la Compañía de Jesús, en que le ruega y encarga mande 24 personas de la Compañía a los lugares que le señale el Consejo de Indias, donde aparece como motivo principal de la regia resolución la conversión de los naturales, es decir, de los indios. La puerta de la evangelización de las Indias Españolas quedaba abierta a la nueva Orden religiosa, que tan maravillosa actividad misionera había desplegado desde sus principios en las Misiones de Oriente y en todas las Indias de Portugal. El Consejo de Indias, después de larga oposición, había roto, por fin, en favor de la Compañía el coto cerrado que era América para las cuatro grandes órdenes de Santo Domingo, San Francisco, San Agustín y la Merced, asociando a la joven Orden a la gran obra que ellas realizaban de infundir la cultura y civilización cristiana en los pueblos americanos" (Mateos 1944 [1600], tomo I: 8).

${ }^{2}$ Agradezco las consideraciones de los evaluadores anónimos de este artículo, en especial aquellas que buscaban alumbrar los procesos de producción de la Relación aquí presentada.

${ }^{3}$ En este plano aparecen las parroquias de Santa Ana y del Hospital de Naturales. Fue confeccionado con motivo de una disputa territorial entre los párrocos de ambas parroquias (Rowe 1989).

${ }^{4}$ No presentamos en esta oportunidad el texto en latín pues corresponde a un añadido y que no guarda relación con las fiestas celebradas 12 años antes.

${ }^{5}$ A diferencia de la Relación limeña, texto homólogo del que presentamos aquí, que es firmada por el Cabildo de Lima.

${ }^{6}$ También con motivo de la beatificación de Ignacio de Loyola, el mismo año, los días 30 y 31 de julio en la ciudad de Lima se realizaron grandes celebraciones, sin embargo, la presencia indígena fue bastante menor (mientras que, por ejemplo, la vascongada fue mucho mayor). Con respecto a las representaciones que hicieron los indígenas se señala lo siguiente: "Esto estaua assí dispuesto, y a las tres y media de la tarde empeçó a salir la processión por este orden. Iban algunas cofradías con diuersas Andas, pendones y cera que trayan y luego vnas Andas de plata llenas de flores de seda y joyas con vn Niño JESVS en ellas muy bien adereçado y a estas y al pendón que delante lleuauan acompañauan los Morenos de la Cofradía de san Salvador, que está en la Compañía. A estas se seguían otro pendón y Andas también de plata, con otro muy hermoso Niño, en traje de Indio, lleno de joyas y riqueza: alumbráuanle los Indios de su Cofradía con muchos y buenos cirios. Siguióse el pueblo del Cercado con cinco Andas y en ellas cinco Imágenes de vulto muy bien hechas con todos sus Pendones. Venían los de este pubelo bien vestidos en su traje, y trayan sus ce[roto] que es mucha y buena [...]" (fol. 14).

${ }^{7}$ En la ciudad del Cuzco se realizaron desde comienzos de la Colonia numerosas fiestas, tanto religiosas como de naturaleza sociopolítica, de gran envergadura. Una de las más ostentosas y que dejó una importante huella en la documentación de la época es el Corpus Christi, en especial el de 1555.

${ }^{8}$ Es importante recordar que en los Andes coloniales el latín fue lengua de evangelización, junto con el castellano, quechua y aymara. Especialmente durante el siglo xvi y comienzos del XVII aún se pretendía que los indígenas aprendiesen el latín al punto que las visitas médicas en el hospital de naturales se realizaban en esta lengua con traducción a las lenguas generales (Martínez 2014).

${ }^{9}$ Hacha: vela de cera, grande y gruesa, de forma por lo común de prisma cuadrangular y con cuatro pabilos (Diccionario de la Lengua Española, en adelante DLE, s.v.).

10 "Festejo de nobles a caballo con vestidos y libreas vistosas, que se ejecutaba de noche, con hachas, corriendo parejas" (DLE, s.v.).

${ }^{11}$ Encuentros o escaramuzas ficticias.

12 "Cada una de las vueltas y tornos que el jinete hace dar al caballo" (DLE, s.v.).

${ }^{13}$ Cazoleta: "Especie de perfume" (DLE, s.v.).

${ }^{14}$ Pebete: "pasta hecha con polvos aromáticos, regularmente en forma de varilla, que encendida exhala un humo muy fragante" (DLE, s.v.).

${ }^{15}$ Muñeco de tamaño natural que se cuelga en los balcones de las casas en época de fiestas, especialmente carnaval.

16 "En juegos y ejercicios de destreza caballerescos, figura giratoria de un hombre armado conun escudo en una mano y una correa con bolas o saquillos de arena en la otra, al que golpeabancon una lanza los participantes, que debían evitar que, al girar, les devolviese el golpe" (DLE, s.v.).

17 "Fiesta de a caballo en la que diferentes cuadrillas hacían escaramuzas arrojándose recíprocamente cañas, de las que se resguardaban con la adarga" (DLE, s.v.).

${ }^{18}$ Corrida de toros.

${ }^{19}$ Corresponde a la actual Plaza de Armas de la ciudad.

${ }^{20}$ Se entiende caballos con sus crines aderezadas y trenzadas.

${ }^{21}$ Pieza ligera de artillería antigua, menor que la culebrina, y esmeril (DLE, s.v.).

${ }^{22}$ Pieza de artillería antigua, pequeña, y algo mayor que el falconete (DLE, S.v.). 
${ }^{23}$ Probablemente consideren como San Sebastián y San Jerónimo las parroquias foráneas. No parece haber alguna relación significativa en el orden de aparición de las distintas parroquias en esta festividad (Belén, Santiago, Hospital de Naturales, San Cristóbal, San Blas, Santa Ana, San Sebastián, San Jerónimo).

${ }^{24}$ Ave de rapiña de colores blanco y negro o gris y sus plumas eran utilizadas para confeccionar la mascapaicha o borla real del Inca.

${ }^{25}$ Suerte de pulsera o argolla de plata.

${ }^{26}$ Diadema.

${ }^{27}$ Cieza de León (1977 [1554]: 107) señaló Ancocagua como uno de los cuatro templos más importantes del Imperio Inca. Aunque no hay descripción o ubicación exacta de este templo, se sabe que allí había un oráculo muy venerado por gente de todas partes del Tawantinsuyu y que correspondía al territorio de los Hatun Canas (Reinhard 1998: 89).

${ }^{28}$ Esta laguna se encuentra en Ecuador y es el lugar donde se llevó a cabo la batalla entre los incas, liderados por Huayna Cápaq y las huestes de la confederación caranquescayambes-otávalos muy pocos años antes de la llegada de los españoles a la región.

${ }^{29}$ No hemos encontrado más referencias sobre esta serpiente. El relato más próximo es el de Pachacuti Yamqui: "En este tiempo dizen que llegó la nueba como en el Cuzco ubo un milagro que como un yauirca o amaro abia salido del serro Pachatuzan muy fiera bestia, media legua de largo y gruesso de dos braças y medio de ancho, y con orejas y colmillos y viene por Yuncay Pampa y Sinca, y de alli entra a la laguna de Quibipay [...]” (1613: f. 21v).

${ }^{30}$ Mora y Odone (2011) entregan datos para pensar la relativa continuidad del culto al Niño Jesús hasta la actualidad, aunque con importantes transformaciones.

${ }^{31}$ Existen muchos más ejemplos de este tipo de representaciones. Uno de ellos es el entregado por Esquivel y Navia: "Domingo 24 de septiembre [1747], hubo una máscara muy lucida de las ocho parroquias que cerraba con un escuadrón de más de 20 incas ricamente vestidos en su bellísimo traje, con sus mascapaychas y al último un carro en que estaban los retratos del rey, nuestro señor, y la reina; y dentro del carro muchos músicos con arpas, guitarras, violines y bandolas, que delante de las casas del cabildo cantaron varios tonos con la armonía de los instrumentos, gran rato y, acabada la música, arrojaron los capitulares porción de plata [...] En esta máscara salieron vestidos 96 incas: los 27 nobles y los demás inferiores" (Esquivel y Navia, II, 405).

${ }^{32}$ Las actualizaciones de estas memorias incaicas parecen haber respondido a distintas lecturas locales y/o contextuales, dando paso a diferentes "ciclos", como el de Guayna Cápaq, el de Huáscar o el de Atahuallpa (Martínez et al. 2018).

\section{REFERENCIAS}

ANónimo. 1610. Relación de las fiestas que en la ciudad del Cuzco se hicieron por la beatificación del bienaventurado padre Ignacio de Loyola. Lima: Imprenta Francisco del Canto.

Beyersdorff, M. 1997. Historia y drama ritual en los Andes bolivianos (siglos XVI-XX). La Paz: Plural-UMSA.

Bradley, P. \& CAHILl, D. 1999. Habsburg Peru: images, imagination and memory. Liverpool: Liverpool University Press.

CABILdo de Lima. 1610. Relación delas fiestas que en la civdad de Lima se hizieron por la beatificación del bienaventurado Padre Ignacio de Loyola, fundador dela Religión dela Compañía de Iesús, hechas imprimir por D. Alonso Bravo de Saravia Soto Mayor. Alcalde de Corte dela Ciudad delos Reyes. <http://bdigital.bnp.gob.pe/Bvirtual/ FlippingBook?URL=http://memoriaperuana.bnp.gob.pe/ bnp/recursos/2/flippingbook/4000003759/index.html> [consultado: 19-01-2019].

Cieza de León, P. 1967 [1554]. El señorío de los Incas. Lima: Instituto de Estudios Peruanos.

De la Puente, J. 2018. Andean cosmopolitans: seeking justice and reward at the Spanish royal court. Austin: Texas University Press.

Esquivel y Navia, D. 1980. Noticias cronológicas de la ciudad del Cusco. Tomos I y II. Lima: Fundación Wiese.

Estete, M. 1533. Noticia del Perú. Biblioteca Peruana. Tomo I. Lima: Editores Técnicos Asociados.

Estenssoro, J. C. 1992. Los bailes de indios y el proyecto colonial. Revista Andina 10 (2): 353-404.

Estenssoro, J. C. 2005. Del paganismo a la santidad. La incorporación de los indios del Perú al catolicismo 1532-1750. Lima: IFEA-Instituto Riva-Agüero.

Flores OchoA, J. 2009. Celebrando la fe. Fiesta y devoción en el Cuzco. Cuzco: UnsaAC-CBC.

Garcilaso de la Vega, I. 1962 [1617]. Historia General del Perú. Lima: Biblioteca de Cultura Peruana, Serie histórica 9.

HeRnándeZ, F. 2013. Los Incas y el poder de sus ancestros. Lima: Pontificia Universidad Católica del Perú.

Hernández, F. \& Cerrón-PAlomino, R. 2015. Juan de Betanzos y el Tahuantinsuyu. Nueva edición de la Suma y Narración de los Incas. Lima: Pontificia Universidad Católica del Perú.

Husson, J. 2005. Entre tradición e innovación. Cinco siglos de literatura amerindia. Lima: Pontificia Universidad Católica del Perú.

Klaiber, J. 2007. Los jesuitas en América Latina, 1549-2000. 450 años de inculturación, defensa de los derechos humanos y testimonio profético. Lima: Fondo Editorial Universidad Antonio Ruiz de Montoya.

MartíneZ, J. L. 2008. Pensarse y Representarse. Aproximaciones a algunas prácticas coloniales andinas de los siglos XVI y XVII. In Lenguajes visuales de los Incas, P. González \& T. Bray, Eds., pp. 147-161. Oxford: B.A.R. International Series 1848 . 
MARTínez, P. 2013. Evangelización andina, educación y castellanización de los indígenas del común. Apuntes sobre el aporte de la Compañía de Jesús. Allpanchis 81-82: 405-436.

Martínez, P. 2014. El castellano y la castellanización de los indígenas del común en el Cuzco colonial (1532-1700): métodos, espacios y prácticas. Tesis para optar al grado de Doctora en Literatura, Universidad de Chile, Facultad de Filosofía y Humanidades.

Martínez, P., Ojalvo, Á. \& Díaz, C. 2011. La construcción de la figura de Pachacuti Inca Yupanqui en los textos coloniales (1534-1615). Revista Diálogo Andino 37: 87-103.

Martínez, P., Martínez, J. L, Díaz, C. \& Odone, C. 2018. La fiesta de las imágenes en los Andes. Santiago: Museo Chileno de Arte Precolombino.

Mateos, F. (Ed.). 1944 [1600]. Historia General de la Compañia de Jesús en la Provincia del Perú. Crónica anónima de 1600 [...]. Tomo II. Madrid: Consejo Superior de Investigaciones Científicas, Instituto Gonzalo Fernández de Oviedo.

Mora, G. \& Odone C. 2011. Niño Jesús en Cusco colonial y Azapa contemporáneo: un ejercicio de análisis de bultos como soportes. Boletín del Museo Chileno de Arte Precolombino 16 (2): 61-74.

Mujica Pinilla, R. 2016. La imagen transgredida: estudios de iconografía peruana y sus políticas de representación simbólica. Lima: Fondo Editorial del Congreso del Perú.
Pardo de Guevara y Valdés, E. 2005. Actas de la XI Reunión Americana de Genealogía. Santiago de Compostela: Artes Gráficas Litonor.

Pizarro, P. 1986 [1572]. Relación del descubrimiento y conquista de los reinos del Perú. Lima: Pontificia Universidad Católica del Perú.

Real Academia Española de la Lengua, Diccionario de la Lengua Española. <dle.rae.es>

REINHARD, J. 1998. The temple of blindness: an investigation of the Inca shrine of Ancocagua. Andean Past 5: 89-108.

Romero, C. 2009. Adiciones a "La imprenta en Lima" de José Toribio Medina. Lima: Pontificia Universidad Católica del Perú-Academia Nacional de la Historia-Universidad San Martín de Porres.

Rowe, J. 1989. El plano más antiguo del Cuzco. Dos parroquias de la ciudad vistas en 1643. Cuzco: Instituto Nacional de Cultura.

Ruiz de PArdo, C. 2004. La jura de Carlos iv en el Cusco. La nobleza indígena reafirma su fidelidad al rey. Revista del Archivo Regional de Cusco 16: 17-27.

Torres, L. 1867. Colección de documentos inéditos del Archivo de Indias. Tomo viII. Madrid: Imprenta de Frías y Compañía.

Valenzuela, J. 2006. Ambigüedades de la imagen en la cristianización del Perú: Trento, los jesuitas y el Tercer Concilio. Investigaciones Sociales x (17): 491-503. 